the Institute during the year ending March 31, 1935. An important development has been a study of practical problems connected with grass conservation, made possible by a commercial grass-drying plant placed at the disposal of the Institute by the Agricultural Research Council. The condensing and drying of milk and the manufacture of canned milk products have also been investigated. Research work includes experiments on the nutritive value of milk for calves, the biochemistry of milk secretion, and studies on bovine tuberculosis, contagious bovine abortion and bovine mastitis. The pasteurization of milk and the bacteriological grading of milk have also been investigated. An inquiry into the consumption of milk by children of school age is in progress. As regards finance, State contributions and grants provide $£ 8,000$ a.year, but an additional $£ 2,000$ per annum is required if the Institute is to carry through its full programme of work.

\section{Social Services in the Soviet Plan for 1937}

According to the Soviet Union Year Book Press Service, the provisions of the 1937 Plan for the national economy of the U.S.S.R. in regard to the cultural and social services include the following: Science. $924 \cdot 2$ million roubles (about $£ 93$ million) for the maintenance of scientific institutions in 1937, as against 797.5 million roubles ( $£ 80$ million) in 1936 . Out of this sum, 245 million roubles (about $£ 25$ million) will be expended on general capital construction for the needs of science, to include an expenditure of 40 million roubles ( $£ 4$ million) on putting up new buildings to house the institutions of the All-Union Academy of Sciences, and 25 million roubles (about $£ 3$ million) for the building of the All-Union Institute of Experimental Medicine. Health Protection. A sum of $7,528 \cdot 1$ million roubles (£753 million) for health protection in 1937, as against $5,803 \cdot 5$ million roubles in 1936 . This sum includes an expenditure of 1,000 million roubles on buildings. The number of hospital beds in 1937 will be increased to 619,800 , as against 564,000 in 1936 ; maternity beds to 11,078 , as against 6,000 in 1936 .

\section{Truth and Propaganda}

AN article by Prof. M. Polanyi in The Manchester School, 7, No. 2, entitled "The Struggle between Truth and Propaganda", although a somewhat polemic criticism of S. and B. Webb's "Soviet Communism : a New Civilization", is of wider interest through its plea for a more determined stand by scientific workers and other intellectual workers for free and impartial criticism against propaganda. Unless thinkers make a fresh stand everywhere, regardless of political consequences, for the criticism which is freely admitted in a democracy, truth will remain powerless against propaganda, the power of which has been immensely enhanced by new means which scientific discoveries and their application have put in its hands. The reconciliation of rival social doctrines, which alone can save Europe from destruction, cannot be attained except through tolerance and the acceptance of truth and facts, no matter how unpalatable or disconcerting to particular theories.

\section{Germany and Science: Yesterday and To-day}

A CoRrespondent has pointed out that the speech at the Heidelberg jubilee by Reichsminister Rust, which was referred to in NATURE of January 16, p. 98, stands in poor contrast to an equally proud speech of Helmholtz delivered in 1869 (Les Mondes, 21, 552). Speaking at Innsbruck at a gathering of German scientific workers and medical men, he claimed that Germany held the first place in the development of natural sciences because the German savants, unlike their French and English colleagues, could proclaim truth as they found it, without regard to the opinion of the world, to social and religious prejudices. Our correspondent remarks that there was more of Athens than of Sparta in such men.

\section{Prof. H. E. Armstrong}

THE familiar and welcome figure of Prof. H. E. Armstrong has been missed in scientific circles for several months; and his caustic comments upon contemporary views and events-both scientific and unscientific-have similarly been absent from the pages of NATURE and of other periodicals. Though, however, general physical weakness prevents Prof. Armstrong from moving about and attending meetings in the way he has done all his life, yet he still takes active interest in progressive work of every kind and asks his friends not to hesitate to com. municate with him. He enters his ninetieth year on May 6, and maintains the indomitable and fearless spirit which has always characterized him. "I should like", he wrote a short time ago to an old friend, "to start over again in the hope that knowledge may be so made use of that some measure of tolerance and common sense will be infused into the nations."

\section{Seventh International Congress of Genetics}

THE following communication has been recoived from Prof. Otto L. Mohr, of the Anatomical Institute, University, Oslo, chairman of the International Committee for Genetics Congresses: "The VIIth International Genetics Congress which was going to be held at Moscow, U.S.S.R. this summer has been postponed. According to the information received from the Organization Committee, a number of scientists and institutes have requested this as they wished to be better prepared for the congress. The Academy of Sciences and the Organization Committee have now extended an invitation to hold the congress in Moscow in August, 1938. Conforming with the mandate given to the Permanent International Committee for Genetics Congresses, the entire matter will be put before this committee for decision. At present it is certain that no International Genetics Congress will be held in 1937."

\section{British Empire Cancer Campaign}

At the quarterly meeting of the Grand Council of the British Empire Cancer Campaign held on April 12 , the following grants, totalling $£ 2,900$, were made, in addition to the bulk grants of last November and January : $£ 1,000$ to be placed at the disposal of 